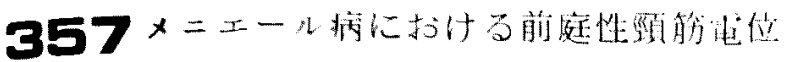

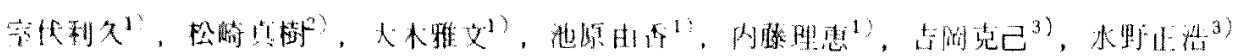

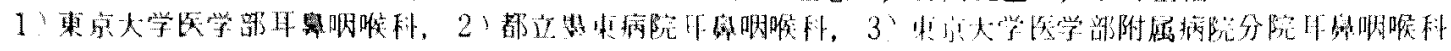

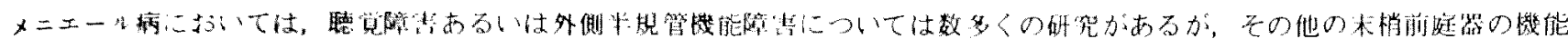

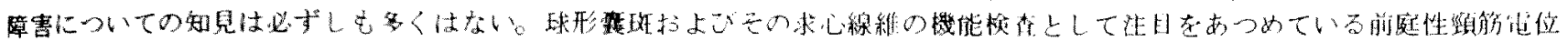

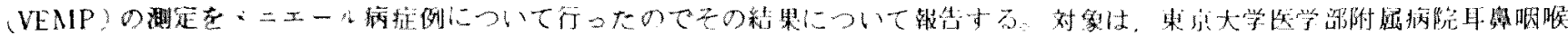

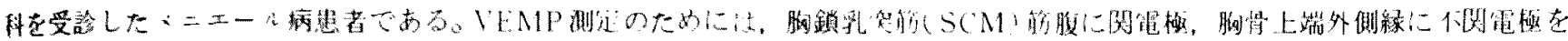

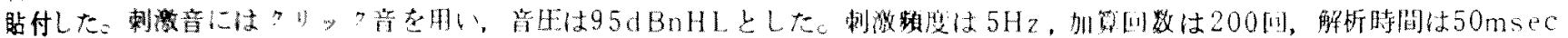

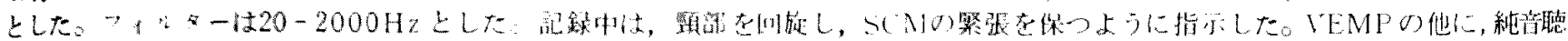

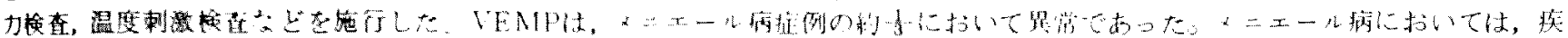

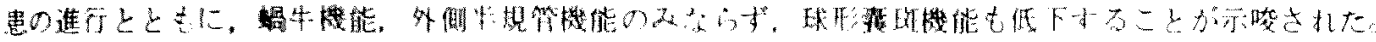

\title{
358 高䕆者にみられるめまいの特徽
}

\section{坂田英治 大都京子 \\ 埼玉医科大学平衡神経科}

\begin{abstract}
高㪸者と若年者を比舫すると、まず第一に気つくことは、前者は脂肪が多く、細胞内水分が著明に少ないことである。 つまり、常に跘水の危啃をはらんでおり、ショックに陷りやすいことでる。

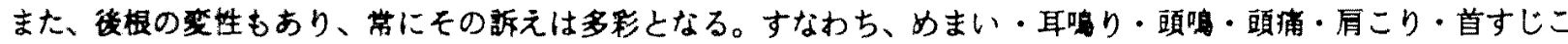

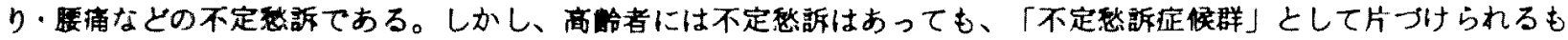

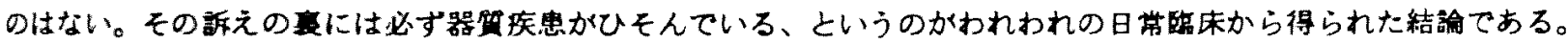
これらのことから高粭者趁薏時、特に注意すへき重項を諭述する。
\end{abstract}

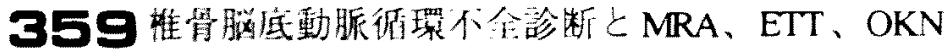

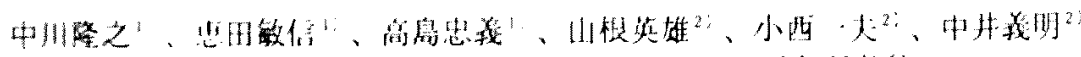

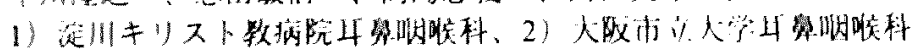

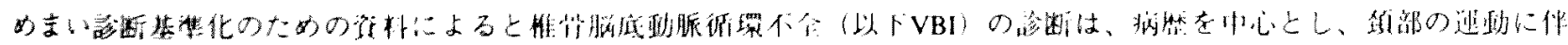

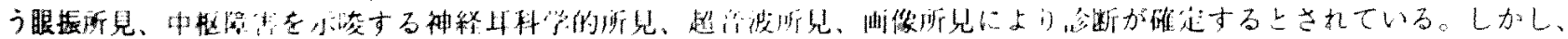

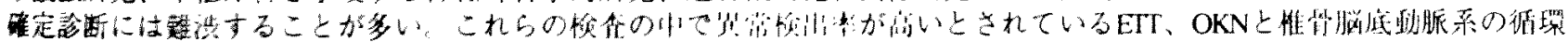

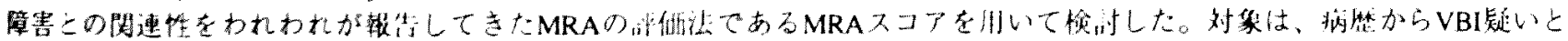

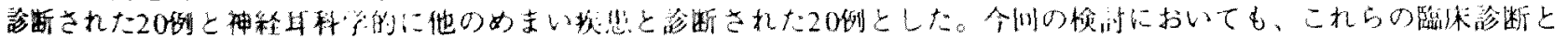

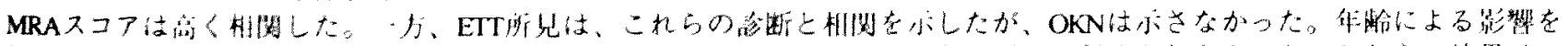

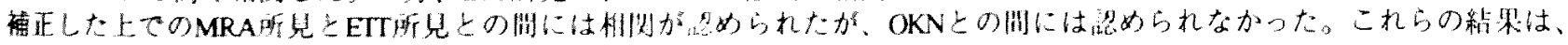

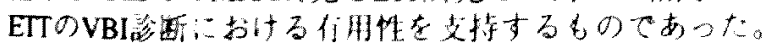

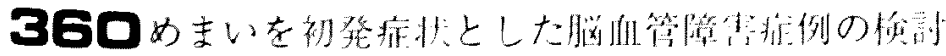

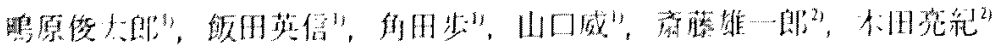

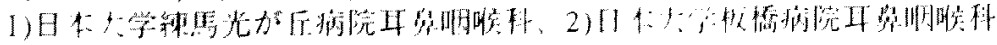

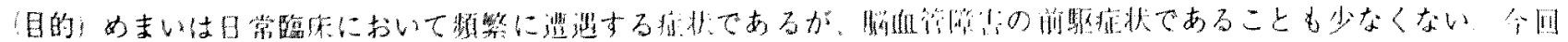

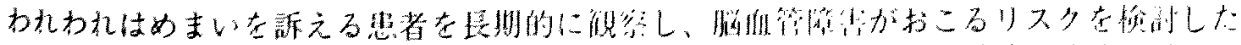

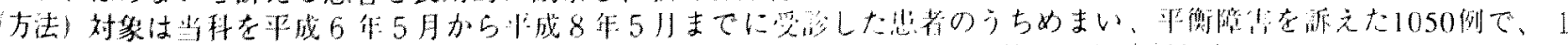

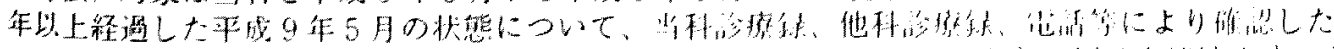

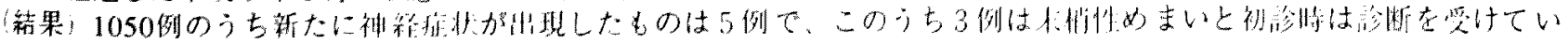

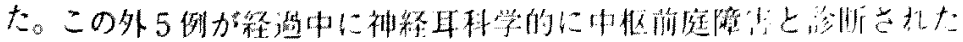

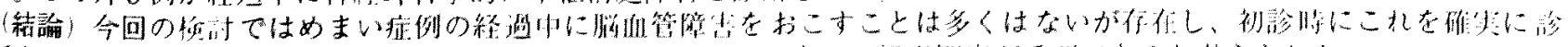

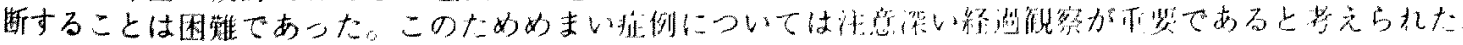

